\title{
Growth, Yield and Grain Quality of Three Maize Varieties and Mungbean under Different Cropping Systems Inoculated with Mykovam ${ }^{\circledR}$
}

\author{
Oliver Musa Lavelah ${ }^{1}$, Ma. Lourdes S. Edaño ${ }^{2}$, Pompe C. Sta. Cruz ${ }^{3}$ and Josefina T. Dizon ${ }^{4}$ \\ ${ }^{1}$ Graduate Student, University of the Philippines Los Baños (UPLB), College, Laguna, Philippines 4030 \\ ${ }^{2}$ Associate Professor, Institute of Crop Science, College of Agriculture and Food Science, UPLB, College, Laguna, Philippines \\ 4030 \\ ${ }^{3}$ Professor, Institute of Crop Science, College of Agriculture and Food Science, UPLB, College, Laguna, Philippines 4030 \\ ${ }^{4}$ Professor, Institute for Governance and Rural Development, College of Public Affairs and Development, UPLB, College, \\ Laguna 4030 \\ DOI: $\underline{\text { https://dx.doi.org/10.47772/IJRISS.2021.5415 }}$
}

\begin{abstract}
Production of green maize in Liberia, Philippines, and other part of the world serves as a whole three fundamental purposes where cobs are consumed directly as food, livestock feed and vegetable oil. This research was performed to determine the yield and yield parameters of maize varieties and mungbean, cropping systems, and inoculation. The research was laid-out under a Randomized Complete Block Design (RCBD) having three open pollinated varieties of maize (IPB Variety 6, IPB 1910 and Los Baños Lagkitan) intercropped with mungbean (Pag-asa 7), and inoculation (Mykovam $\left.{ }^{\circledR}\right)$ under 14 cropping systems. Plant height, Leaf Area Index (LAI), and Light attenuation (k) were measured as agronomic parameters. Weight of unhusked ear ${ }^{-1}$, marketable ear, ear ${ }^{-1}$ length, number of kernels ear ${ }^{-1}$, and a hundred (100) kernels weight were measured as yield parameters of maize. IPB Variety 6 stands as the exceptional variety for growth, yield and productivity, with the highest yield among the three maize varieties. There was better grain quality in the intercropped with inoculation than monocropped and uninoculated intercropped. Los Baños Lagkitan intercropped mungbean and Mykovam inoculation achieved the highest crude protein among the three varieties in the research.
\end{abstract}

Keywords: Growth and yield, maize varieties, cropping system, Mykovam inoculation

\section{INTRODUCTION}

G rowing two or more crops in mixed stands has been, and continues to be a tradition in subsistence farming in Liberia and the Philippines Dingkuhn,el at(2006). Farmer's experience over the years and the results of numerous studies on multiple cropping have confirmed that there exists a potential for obtaining yield advantage by growing more than one crop simultaneously on a given piece of land. Until recently, it has been suggested that growing crops in association, as in intercropping, allows efficient utilization of the environmental resources (Deininger \& Byerlee, 2011). However, the underlying principles leading to efficient resource use by intercrops has remained obscure (LaCanne, 2017). Elucidation of the mechanisms of how much efficiency is achieved by the crops grown in the mixture would enable the agronomist to manipulate the component technologies of multiple cropping systems for further benefits of the farmers (LaCanne, 2017).

Intercropping cereals with low-canopy legumes is widely practiced in many countries (Matusso,et al 2014), among which intercropping of maize (Zea mays L.) and mungbean (Vigna radiata L.) has been studied by many authors as alternative production strategy and was reported to have produced a high yield and better grain quality thus improving agricultural productivity (Ananthi et al., 2017). There are many advantages of intercropping which lead to productiveness, but there are factors that need to be considered for the cropping system to be effective and minimize the competition, namely, a) plant density, b) plant architecture, c) spatial arrangement, and d) the maturity date of the crops to be grown. The production of legumes cereal intercrops for animal feed may also increase the selfsufficiency of organic farms provided that the concentrates have satisfactory protein content and quality. This can also assist the farmer to be more independent, offering predictable and possibly lower prices for fodder (Pozdisek et al., 2011). One of the principal motives behind intercropping around the world is greater productivity than monocropping on the same land size (Mousavi \& Eskandari,(2011)

According to Chakraborty et al. (2012) dry matter production in wheat and beans intercrop had been greater than when planted as monocrop. Mousavi, S. R., \& Eskandari, H. (2011) suggested similar results with grain and dry matter yield in bean and barley intercropping. Intercropping is an economic method for higher production with lower levels of external inputs. This increasing use efficiency is important, especially for small scale farmers and also in areas where the growing season is short (Altieri et al., 2012). Greater production in intercropping can be attributed to greater growth rate, reduction of weeds, reduction of pests and diseases, and extra effective use of valuable resources due to differences in resource consumption and according to Lithourgidis,et al (2011), sweet pea yield increases when planted as intercrops. 
The beneficial effect of mycorrhizal colonization on many field crops has been proven. In wheat crop, the mycorrhizal colonization is greater in well-watered plants while lower in water-stressed plants. The arbuscular mycorrhizal fungi(AMF) had a high-quality effect on many field crops. Mykovam inoculation is generally accepted to continuously enhance the productivity of maize crop (Cely et al., 2016). Furthermore, the impact of mycorrhizal inoculation on hundred seed weight, seed wide maize variety per ear ${ }^{-1}$, and grain yield was demonstrated to be efficient according to Masoero \& Giovannetti, 2015).

Yield and grain quality advantage in intercropping may also take place due to the fact that component differs in their use of growth factors in such a way that when grown in mixture they can complement each other and make higher overall use of resources than when grown separately. This complementarity can be temporary and/ or spatial. Temporal complementarity in useful resource use occurs when the growth pattern of the component crops differ in time Forrester, D. I. (2014). A combined leaf canopy may additionally make better spatial use of light, or a combined root system may also make better spatial use of nutrients and /or water. However, it was once pointed out that even though spatial arrangement can be beneficial but there is theory to distinguish between temporal and spatial effects, in practice they are often separated (Van Noordwijk et al., 2015). This research sought to evaluate growth, yield and grain quality of three maize varieties and mungbean under different cropping systems inoculated with Mykovam ${ }^{\circledR}$.

\section{MATERIALS AND METHODS}

\section{Time and Place of the Research}

The research was conducted at the Central Experiment Station (CES), University of the Philippines Los Baños, College, Laguna, Philippines from December 8, 2019 to February 8, 2020.

The total monthly rainfall distribution, relative humidity and temperature (maximum and minimum) during the experiment were obtained from the National Agromet Station, University of the Philippines Los Baños, College, Laguna.

\section{Experimental Design and Treatments}

The research has three variables; cropping systems (monocrop and intercrop), maize varieties (3) and Mykovam ${ }^{\circledR}$ inoculations (with and control/without). The research was laid-out in Randomized Complete Block Design (RCBD) with three replicates. Maize varieties used are open-pollinated namely: IPB 6, IPB 1910, and Los Baños Lagkitan.

\section{Experimental Area}

The experimental area occupied $1,263.5 \mathrm{~m}^{2}$; each block measured $45.0 \mathrm{~m} \times 10.5 \mathrm{~m}\left(441 \mathrm{~m}^{2}\right)$ while each plot is $6.0 \mathrm{~m} \times 5.0 \mathrm{~m}\left(30.0 \mathrm{~m}^{2}\right)$.

\section{Planting}

Two seeds of maize per hill were planted with the standard spacing of $0.75 \mathrm{~m} \times 0.25 \mathrm{~m}$ of maize and mungbean intercropping system. The seeds were covered with $2 \mathrm{~cm}$ soil. Thinning was done and only one plant per hill was maintained 15 days after planting (DAP). Each plot contains 8 rows with 20 plants per row and a total of 160 plants per plot, maintaining a plant population of 53,333 plants per hectare.In each treatment, except the control (monocrop), mungbean seeds were intercropped between the rows of maize. Each row was $0.5 \mathrm{~m}$ apart and $0.25 \mathrm{~m}$ between hills. Under monocrop mungbean, there are 80,000 plants per hectare of total mungbean plants. There were a total of 12 rows with 20 plants per row constituting a plant population of 240 plants per plot, 80,000 plants per hectare. For the intercropping, mungbean seeds were sown in between fallow and or rows of maize.

\section{Crop Management}

\section{Maize Varieties Used}

Corn varieties used were IPB Var 6, IPB 1910, Los Baños Lagkitan and Pag-asa 7 for mungbean. All the seeds were obtained from the Institute of Plant Breeding (IPB), College of Agriculture and Food Science (CAFS), University of the Philippines Los Baños (UPLB), College, Laguna (IPB, 2008).

\section{Fertilizer application}

The rate of fertilizer applied was based on the recommended rate of 80,60,60; and the correct amounts of fertilizer were computed and applied (Chapoto et al., 2016). The recommended rate is expressed as $\mathrm{N}, \mathrm{P}$ and $\mathrm{K} \mathrm{Kg} \mathrm{ha}{ }^{-1}$, respectively.

\section{Inoculation}

Mykovam ${ }^{\circledR}$ is a fungi-based bio-fertilizer developed by UPLB-BIOTECH. Mykovam is a soil-based bio fertilizer, which has effective species of fungi call vesicular arbuscular mycorrhiza (VAM). The fungi inoculates the roots, form a close association with the plant when inoculated to the seedlings and assists the plant in the absorption of water and nutrients. The fungi also prevent root infection by pathogens and increase plant tolerance to drought and heavy metals Rola, A. C. (2000).

This mycorrhizal inoculant is composed of spores, infected roots and other infective propagules of endomycorrhizal fungi. Mykovam ${ }^{\circledR}$ was applied as slurry to the seeds and sprayed for the second and third applications. Nine packs per hectare (each pack contains $300 \mathrm{~g}$, a total of 2,700 g) were used. At sowing, seven packs $(2,100 \mathrm{~g})$ were coated onto slightly moistened seeds, the second application was sprayed (dissolved $300 \mathrm{~g}$ or 1 pack to $32 \mathrm{~L}$ of water) 10 days after sowing (DAS), and the third application was sprayed (dissolved 1 pack to $32 \mathrm{~L}$ of water) at 20 DAS. 


\section{Weeding and thinning}

Seedlings were thinned to one plant per mount and or planting station to obtain the desired plant population between 7-15 DAS and emergence. Weeding was done three (3) times, at 15, 25 and 40 DAS. Supplemental irrigation was provided to the plants when needed. Water stress was avoided as much as possible. Furadan $3 \mathrm{G}$ at $0.5 \mathrm{~kg}$ per hectare was applied in furrows along with fertilizers before planting for initial control of insect pests. Additional application of Furadan $3 \mathrm{G}$ was made in the maize at 30 DAP for the proper control of shoot borers. Azodrin was sprayed alternatively on both mungbean and maize at 45 DAP. Both maize and mungbean were harvested manually. Priming was the mode of harvesting of mungbean. The pods were shelled manually. Maize was harvested after 87 DAP and at 60, 6876 DAP for mungbean. Maize was harvested when the green leaves turned yellowbrown, the husk became brown or it reached its maturity period. This was determined by detaching few kernels from the cob to see if there is already the formation of a black layer on the kernels. Mungbean was harvested when the pod becomes dark brown to black. Mungbean matures after 62-74 days from seedlings. Grain moisture content was determined after sun drying for 14 days (two weeks) using a steinlite tester (Steinlite NTEP Moisture Tester SL95).

\section{Data Gathering}

The data collection on plant height was done at 30, 45 and 60 days after planting for maize and 15, 30 and 45 days after planting for mungbean.

\section{Agronomic parameters}

For plant height $(\mathrm{cm}), 10$ plants were selected randomly and tagged from each plot. Plant height was measured from the soil surface to the tip of the fully expanded leaves 15 days from 30 DAP and at the tip of the tassel at flowering stage. The LAI is the total functional leaf area per unit ground area. Three plants were selected randomly from each plot. The LAI was measured at 75 DAP, the ending of the entire experiment to avoid destructive sampling.

The LAI was calculated as follows:

\section{$\mathrm{LAI}=\underline{\text { Total leaf area }}$}

\section{Total Ground area}

\section{Light attenuation down the canopy}

This was measured in the field at different canopy levels: upper leaf; middle leaf; and lower leaf levels. This parameter was determined using the model of light meter brand MQ-303 and used the formula.

$\mathrm{I}=\mathrm{I}_{0} \mathrm{e}^{-\mathrm{kl}}$

Where:

$\mathrm{I}_{0}=$ is the irradiance above crop canopy
$\mathrm{I}=$ irradiance at a point in the canopy above which there is a leaf area index of L. Both $\mathrm{I}_{0}$ and I measured horizontally disposed of sensors and $\mathrm{k}$ and $\mathrm{L}$ are dimensionless.

$\mathrm{S}=\mathrm{e}^{-\mathrm{k}}$ is used in place of $\mathrm{k}$ (as the natural logarithm, linear attenuation factor).

Three canopy layers were measured; above canopy, middle level canopy and below canopy. From the surface, $12 \mathrm{~cm}$ high and the upper part from lower was divided by two to indicate the middle and upper layer (Upper = Middle $)$.

\section{Yield Parameters}

Maize samples for yield parameters are similar to those tagged for plant height sample.

The number of ears per plant. The number of ears was counted, recorded and the average number of ears per plant was calculated.

Ear length $(\mathrm{cm})$. This was measured without husk and the average length was calculated.

Marketable ear ${ }^{-1}$ weight $(g)$. This was measured without husk and the average weight was calculated.

Average ear ${ }^{-1}$ weight ( $g$ / plant). Ear weight (husk plus cob) was determined, marketable weight and weight per plant was calculated.

Number of kernels per ear. The cob was removed and the number of kernels was counted and the average was calculated.

Grain weight (g/plant). The cob was removed and only the grains were weighted and the average was calculated.

One thousand seeds weight $(g)$. One thousand seeds were counted and weighed.

Total ear weight $\left(\mathrm{kg} \mathrm{m}^{-2}\right)$. This was determined from $4 \mathrm{~m}^{2}$ harvest area at the inner rows. Grains, cob and husk weights were recorded and their averages were calculated.

Total yield (14\% moisture content, $\left.m g \mathrm{~m}^{-2}\right)$. This was converted to the total weight from $4 \mathrm{~m}^{2}$ to hectare. All yields were expressed in dry grain 14\% moisture content (MC) basis and estimated at $28-30 \% \mathrm{MC}$ during harvest, using the following formula:

Y-Y1- $\left[\frac{(100-M C)}{86}\right]$

Grain quality crude protein. One thousand seeds from each treatment was ground and the crude protein content from them was taken to the Laboratory for analysis, $\mathrm{NH}_{4}{ }^{+}$content was calculated (Kjeldahl Method) Official Methods of Analysis of AOAC International, 16th edition.

\section{Statistical Analysis}

The homogeneity and normality of the data were tested using Bartlette levene and Shapero Wilk's test, 
respectively. The data were subjected to ANOVA using the International Rice Research Institute (IRRI) Statistical Tool for Agricultural Research (STAR). The relationship between the selected parameters was determined using correlation and regressions analysis. Treatment means were compared using Tukey's Honest Significant Difference (HSD).

\section{RESULTS AND DISCUSSION}

It was hypothesized that intercropping maize with mungbean and with the application of Mykovam $^{\circledR}$ as inoculated three maize varieties under different cropping systems will have a better growth, high yield advantage; better grain quality. The result of this research did support the hypothesis that cropping systems, varieties and inoculation impacts the yield and grain quality of maize. Intercropping IPB Var 6 with mungbean and with inoculation resulted to greater growth, higher yield, and grain quality. Higher yield was associated with variety with uniform height; (Tokatlidis et al., 2004) hence, height is a good indicator. LAI is associated with cropping system and varieties as it is an index of photosynthetic rate and is described as the achievable harvesting surface per unit area Fang et al. (2014).

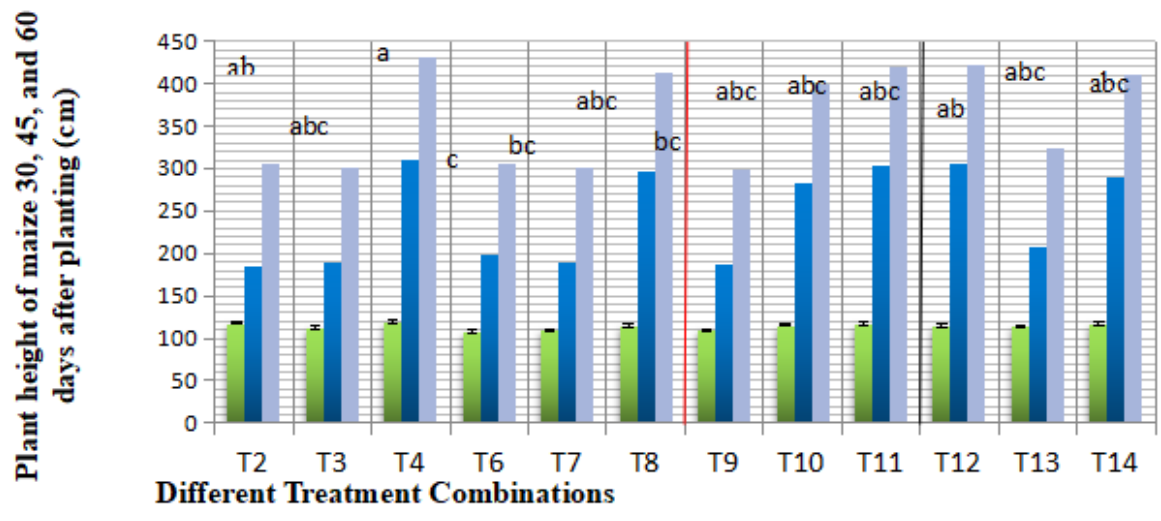

Figure 1. Effect of maize variety, cropping systems and inoculation on plant height of maize at 30, 45, and 60 DAP. Green bars indicate 30 DAP, Blue bars indicate 45 DAP and gray Bars indicate, T9-T11 intercrop and T12-T14 intercrop and inoculated with Mykovam ${ }^{\circledR}(\mathrm{SE}=1.53,19.40$, and 19.60$)$

Cropping system, varieties, and inoculations influenced the LAI. Intercropped maize with inoculation achieved the highest LAI and monocropped without inoculation accounted for the lowest. Additionally, LAI was dependent on varieties, as Los Baños Lagkitan accounted for the least among the varieties with or without inoculation. LAI was related to multiple factors including site quality (climate and soils) and shade tolerance and the three maize varieties growth rates. Rainfall and water supply and evapotranspiration rates are proportional to LAI and reductions, with the unprecedented rainfall during the period of the research, and higher temperature which contributed high foliar respirations. There was higher moisture content in intercrop compared to monocrop and moisture content crop growth rates potentially influence the LAI.

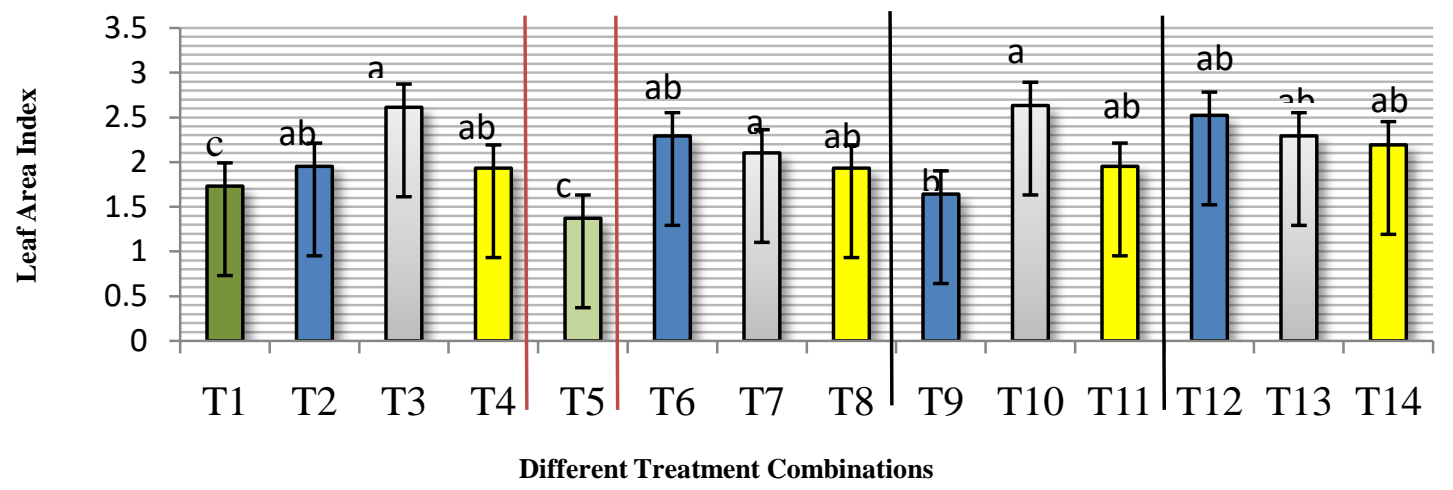

Figure 2. Effect of maize variety, cropping systems and inoculation on LAI at 60 DAP. Blue bars indicate IPB Var 6, gray bars = IPB 1910, yellow = Los Baños Lagkitan, T1 (dark green) monocrop mungbean, T2-T4 monocrop maize, T5 (olive green) monocrop mungbean inoculated, T9-T11 intercrop and T12-T14 intercrop and inoculated $(\mathrm{SE}=0.2596)$ 
The number of maize ears per plant was extensively affected by the variety and cropping systems (Table 1), IPB Variety 6 had consistently the highest number of ears per plant acrosstreatment, followed by IPB 1910, and Los Baños Lagkitan, Maize unhusked ear/unmarketable ear weight was appreciably influenced by the interactions between the varieties, the cropping system, and inoculation, (Table 1). IPB Variety 6 had the heaviest unhusked ear weight in monocrop, intercrop and inoculation, followed by IPB 1910, and Los Baños Lagkitan. The maize marketable ear weight was notably influenced by the interaction between the varieties, cropping systems and inoculation (Table 1). IPB Variety 6 consistently maintained the heaviest marketable ear weight due to the large size of the kernels.Maize Ear length was influenced by the interaction between the varieties, cropping system and inoculation (Table 1). IPB Var 6 relatively had the longest ear among the varieties in the research. The numbers of maize kernels per ear was influenced by the interaction between the varieties, cropping system and inoculation (Table 1). Los Baños Lagkitan had the shortest ear length and lighter grain weight and this was due to the smaller size of the kernels, but with the highest number of kernels per ear. Therefore, the research suggest that the smaller the grain, the more the kernels and the lighter the kernels, meanwhile, the larger the kernels, the lesser the number of kernel per cob vice versa.

Table 1. Growth and Yield parameters of maize (Zea mays L.) as affected by Varieties, cropping systems and inoculation

\begin{tabular}{|c|c|c|c|c|c|c|c|c|}
\hline & & & IAIZE YIELD & RAMETE & & & & \\
\hline TREATMENT & $\begin{array}{l}\text { No of ears } \\
\text { Plant }^{-1}\end{array}$ & $\begin{array}{l}\text { Unhusked } \\
\text { ear weight } \\
(\mathrm{g})\end{array}$ & $\begin{array}{l}\text { Marketable } \\
\text { ear weight }\end{array}$ & $\begin{array}{l}\text { Ear } \\
\text { Length } \\
(\mathrm{cm})\end{array}$ & $\begin{array}{l}\text { No. of } \\
\text { Kernels } \\
\text { ear }^{-1}\end{array}$ & $\begin{array}{c}1000 \\
\text { seeds } \\
\text { weigh } \\
(\mathrm{g})\end{array}$ & LAI & k Light \\
\hline $\mathbf{T} 2$ & $1.77 \mathrm{abc}$ & $235.22 \mathrm{a}$ & $231.00 \mathrm{ab}$ & $16.89 \mathrm{a}$ & $304.33 \mathrm{c}$ & $438.67 \mathrm{a}$ & $1.95 \mathrm{ab}$ & $1.93 \mathrm{a}$ \\
\hline T3 & $1.44 \mathrm{abc}$ & $203.44 \mathrm{abc}$ & $199.56 \mathrm{bcd}$ & $13.50 \mathrm{~b}$ & $340.11 \mathrm{~b}$ & $348.00 \mathrm{~b}$ & $2.61 \mathrm{a}$ & $1.8 \mathrm{ab}$ \\
\hline T4 & $1.33 \mathrm{bc}$ & $176.77 \mathrm{c}$ & $172.78 \mathrm{~d}$ & $12.67 \mathrm{~b}$ & $411.44 \mathrm{a}$ & $274.78 \mathrm{c}$ & $1.93 \mathrm{ab}$ & $1.40 \mathrm{~cd}$ \\
\hline T6 & $2.00 \mathrm{a}$ & $231.44 \mathrm{ab}$ & $216.33 \mathrm{abc}$ & $16.68 \mathrm{a}$ & $302.67 \mathrm{c}$ & $424.00 \mathrm{a}$ & $2.29 \mathrm{ab}$ & $1.80 \mathrm{ab}$ \\
\hline T7 & $1.22 \mathrm{c}$ & $212.11 \mathrm{abc}$ & $197.67 \mathrm{~cd}$ & $13.49 \mathrm{~b}$ & $336.56 \mathrm{~b}$ & $347.44 \mathrm{~b}$ & $2.10 \mathrm{ab}$ & $1.6 \mathrm{abc}$ \\
\hline T8 & $1.33 \mathrm{bc}$ & $192.44 \mathrm{bc}$ & $188.00 \mathrm{~cd}$ & $12.89 \mathrm{~b}$ & $418.00 \mathrm{a}$ & $272.11 \mathrm{c}$ & $1.93 \mathrm{ab}$ & $0.97 \mathrm{ef}$ \\
\hline T9 & $1.88 \mathrm{ab}$ & $237.33 \mathrm{a}$ & $233.33 \mathrm{a}$ & $17.31 \mathrm{a}$ & $306.44 \mathrm{c}$ & $420.11 \mathrm{a}$ & $1.64 \mathrm{~b}$ & $1.70 \mathrm{abc}$ \\
\hline T10 & $1.33 \mathrm{bc}$ & $209.44 \mathrm{abc}$ & $205.00 \mathrm{abc}$ & $13.22 \mathrm{~b}$ & $340.78 \mathrm{~b}$ & $342.56 \mathrm{~b}$ & $2.63 \mathrm{a}$ & $1.50 \mathrm{bcd}$ \\
\hline T11 & $1.33 \mathrm{bc}$ & $193.22 \mathrm{bc}$ & $189.11 \mathrm{~cd}$ & $13.11 \mathrm{~b}$ & $418.44 \mathrm{a}$ & $272.67 \mathrm{c}$ & $1.95 \mathrm{ab}$ & $0.80 \mathrm{f}$ \\
\hline T12 & $1.88 \mathrm{ab}$ & $235.55 \mathrm{a}$ & $231.44 \mathrm{a}$ & $17.42 \mathrm{a}$ & $307.00 \mathrm{c}$ & $419.11 \mathrm{a}$ & $2.52 \mathrm{ab}$ & $1.43 \mathrm{bcd}$ \\
\hline T13 & $1.33 \mathrm{bc}$ & $213.33 \mathrm{abc}$ & $209.22 \mathrm{abc}$ & $13.44 \mathrm{~b}$ & $340.00 \mathrm{~b}$ & $355.78 \mathrm{~b}$ & $2.29 \mathrm{ab}$ & $1.27 \mathrm{de}$ \\
\hline T14 & $1.33 \mathrm{bc}$ & $191.89 \mathrm{bc}$ & $187.78 \mathrm{~cd}$ & $12.78 \mathrm{~b}$ & $421.22 \mathrm{a}$ & $277.56 \mathrm{c}$ & $2.19 \mathrm{ab}$ & $0.80 \mathrm{f}$ \\
\hline \multicolumn{9}{|l|}{ Mean } \\
\hline & 1.51 & 211.02 & 205.1 & 14.45 & 353.9 & 349.4 & 2.2 & 1.422 \\
\hline \multicolumn{9}{|l|}{ Significance } \\
\hline Varieties (V) & $* *$ & $* *$ & $* *$ & $* *$ & $* *$ & $* *$ & $* *$ & $* *$ \\
\hline $\begin{array}{l}\text { Cropping System } \\
\text { (CS) }\end{array}$ & $* *$ & $* *$ & $* *$ & $* *$ & $* *$ & $* *$ & $* *$ & $* *$ \\
\hline Inoculation (I) & $*$ & $*$ & $*$ & $*$ & $*$ & $*$ & $*$ & $*$ \\
\hline Blocks (B) & $\mathrm{ns}$ & ns & $\mathrm{ns}$ & Ns & ns & Ns & $\mathrm{ns}$ & $\mathrm{ns}$ \\
\hline CS X I & $*$ & $*$ & $*$ & $*$ & $*$ & $*$ & $*$ & $*$ \\
\hline Var x CS x I & $* *$ & $* *$ & $* *$ & $* *$ & $* *$ & $* *$ & $* *$ & $* *$ \\
\hline $\begin{array}{l}\text { Var x B } \\
\text { HSD }_{0.05}\end{array}$ & $\mathrm{~ns}$ & $\mathrm{~ns}$ & $\mathrm{~ns}$ & Ns & Ns & Ns & $\mathrm{ns}$ & $\mathrm{ns}$ \\
\hline
\end{tabular}

The growth and yield of maize varieties in this research were interdependent on the cropping system, varieties, inoculations, whereas other management practices are at recommended levels. Maize yields and mungbean intercropped were significantly enhanced via cropping system, varieties, and Mykovam inoculation. The differences in growth between treatments were significant $(\mathrm{P}<0.05)$ throughout the cropping system and inoculation. Growth and yield of maize were dependent on the cropping system, varieties, and inoculation.For grain yield of maize at $14 \%$ MC, IPB Variety 6 (monocropped with inoculation) had the highest yield (6.03 $\mathrm{Mg} \mathrm{ha}^{-1}$ ) among the cropping system. The 
yield levels of monocropped maize with and without inoculation (5.3 $\mathrm{Mg} \mathrm{h}^{-1}$ and $5.4 \mathrm{Mg} \mathrm{ha}^{-1}$ ) and intercropped with mungbean $\left(5.96 \mathrm{Mg} \mathrm{ha}^{-1}\right)$, without inoculation did not differ. The lowest yield (5.04 $\mathrm{Mg} \mathrm{ha}^{-1}$ ) was obtained in Los Baños Lagkitan monocropped, with and without inoculation (Table 2), although not significantly different with intercropped with mungbean and inoculation.

Monocropped mungbean with inoculation had the greatest seed yield $\left(1.73 \mathrm{Mg} \mathrm{ha}^{-1}\right)$ in contrast to other cropping systems
(Table 2), even though the monocropped mungbean without inoculation $\left(1.60 \mathrm{Mg} \mathrm{ha}^{-1}\right)$ did not significantly differ. Mungbean yield did not significantly differ when intercropped with IPB Variety 6 with or without inoculation, but considerably differed when intercropped with Los Baños Lagkitan. The height of the maize varieties influenced the growth of the mungbean.

Table 2. Yield of maize (Zea mays L.) and mungbean (Vigna radiata L.) as affected by Varieties, cropping systems and inoculation

YIELD (Mg ha $\left.{ }^{-1}, 14 \% \mathrm{MC}\right)$

\begin{tabular}{|c|c|c|}
\hline & & \\
\hline & Maize & Mungbean \\
\hline T1-Monocrop mungbean & -- & $1.602 \mathrm{ab}$ \\
\hline T2-Monocrop IPB Variety 6 & $5.96 \mathrm{ab}$ & --- \\
\hline T3-Monocrop IPB 1910 & $5.32 \mathrm{c}$ & --- \\
\hline T4-Monocrop Los Baños Lagkitan & $4.62 \mathrm{de}$ & --- \\
\hline T5-Monocrop Mungbean + Mykovam ${ }^{\circledR}$ & --- & $1.72 \mathrm{ab}$ \\
\hline T6-Monocrop IPB Variety $6+$ Mykovam $^{\circledR}$ & $5.84 \mathrm{ab}$ & --- \\
\hline T7-Monocrop IPB 1910 + Mykovam ${ }^{\circledR}$ & 5.40 & --- \\
\hline T8-Monocrop Los Baños Lagkitan + Mykovam ${ }^{\circledR}$ & $5.03 \mathrm{de}$ & --- \\
\hline T9-Intercrop IPB Variety $6+$ mungbean & $5.73 \mathrm{ab}$ & $1.43 \mathrm{c}$ \\
\hline T10-Intercrop IPB 1910 + mungbean & $5.51 \mathrm{abc}$ & $1.49 \mathrm{c}$ \\
\hline T11-Intercrop Los Baños Lagkitan + mungbean & $5.26 \mathrm{c}$ & $1.31 \mathrm{~d}$ \\
\hline T12-Intercrop IPB Variety $6+$ mungbean + Mykovam ${ }^{\circledR}$ & $5.82 \mathrm{ab}$ & $1.52 \mathrm{c}$ \\
\hline T13-Intercrop IPB 1910 + mungbean + Mykovam ${ }^{\circledR}$ & $5.65 \mathrm{abc}$ & $1.43 \mathrm{c}$ \\
\hline T14-Intercrop Los Baños Lagkitan + mungbean + Mykovam ${ }^{\circledR}$ & $5.33 \mathrm{c}$ & $1.24 \mathrm{~d}$ \\
\hline Mean & 5.46 & 0.66 \\
\hline
\end{tabular}

\begin{tabular}{lcc}
\hline \hline Significance & & $* *$ \\
Cropping System (CS) & $* *$ & $* *$ \\
Variety (Var) & $*$ & $*$ \\
Inoculation (I) & $\mathrm{ns}$ & $\mathrm{ns}$ \\
Blocks (B) & $*$ & $*$ \\
Var x CS & $*$ & $*$ \\
Var x I & $* *$ & $* *$ \\
Var x CS x I & $\mathrm{ns}$ & $\mathrm{ns}$
\end{tabular}

HSD $_{0.05}$

Means followed by different letters within each column are significant at alpha $=0.05$

$*=$ significant, $* *$ highly significant, ns not significant

The yield of the maize was influenced by the three varieties. The weather and soil conditions of the research site and the ability of a variety to tolerate the adverse climatic condition may have potentially influenced the yield. Observably, there was higher moisture contend in the intercropped compared to monocrop. The observed moisture content may have helped to alleviate the adverse climatic conditions thereby improving yields of the intercrop. The ability of the intercropping component to convert the applied fertilizer to dry matter may have also influenced the yield. The yield of mungbean was influenced by the cropping system and inoculation. Monocropped mungbean with inoculation achieved the highest yield $\left(1.73 \mathrm{t} \mathrm{ha}^{-1}\right)$ accompanied by monocropped mungbean without inoculation $\left(1.602 \mathrm{t} \mathrm{ha}^{-1}\right)$. Meanwhile, mungbean intercropped with IPB Variety 6 with inoculation achieved the highest yield $\left(1.52 \mathrm{t} / \mathrm{ha}^{-1}\right)$. This 
research established that IPB Variety 6 with Mykovam inoculation is recommended for intercropping mungbean, due to the fact that mungbean achieved higher yield under this management practice and cropping system and Los Baños Lagkitan is recommended due to its yield advantage over monocrop of the same variety
From the laboratory analysis assessing the protein content of the three varieties of maize as affected by variety, cropping system and inoculation, the highest of the crude protein of maize was obtained in T-11: Los Baños Lagkitan intercropped mungbean and Mykovam inoculation $8.98 \pm 0.13$, and the lowest crude protein was obtained in T-3: Monocrop IPB 1910 without Mykovam inoculation $6.90 \pm 0.39$ (Figure 3)

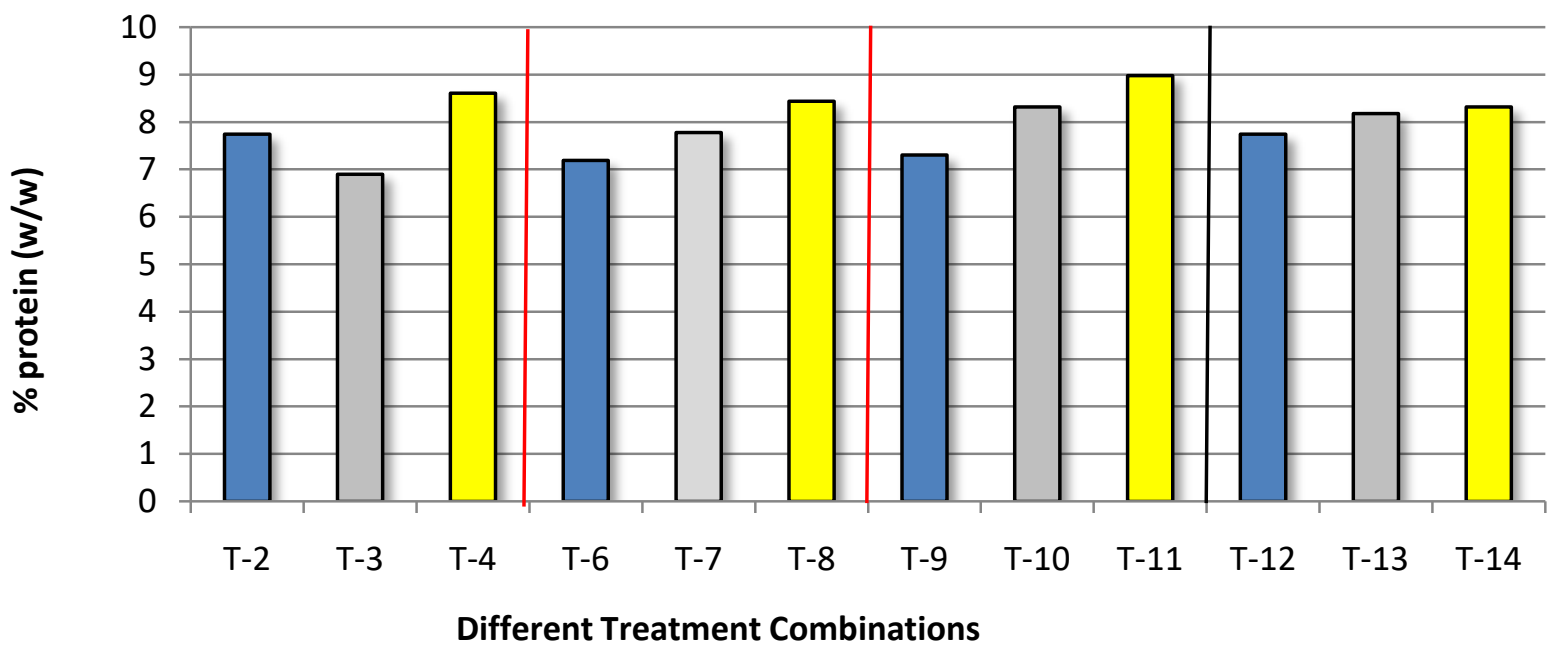

Figure 4. Crude protein per treatment (Kjeldahl MethodFigure), Effect of variety, cropping system, and inoculation on crude protein content, Blue bars indicate

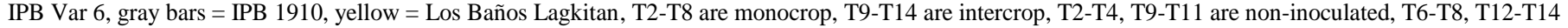
are inoculated and no crude protein extracted for T1 and T5 were monocrop mungbean

Protein levels of maize can be improved with the correct balance of nutrition, particularly nitrogen, phosphorus, sulphur and zinc which will improve grain protein content and quality Duncan et al. (2018). The application of fertilizer may have influenced the protein content and each maize varieties had a unite characteristics that may them different from each other. Los Baños Lagkitan has tall crop characteristics which enables it to absorb higher photosynthates and conversion to dry matter. The three maize varieties in the research had different physiological characteristics and different level of infections by inoculants and conversion potential may have greatly influenced the crude protein. The symbiotic interaction between Mykovam and the host legumes that established the biological nitrogen fixation may have improved the protein. The results suggest that Los Baños Lagkitan had higher conversions potential and higher level of dry matter production compared to the IPB var6 and IPB 1910. Mykovam ${ }^{\circledR}$ inoculation and cropping systems significantly influenced the protein content of the maize.

\section{CONCLUSION}

Even though growth, yields and grain quality are the fundamental issues confronting maize production in Liberia and Philippines, nevertheless, under maize-legume intercropping and Mykovam ${ }^{\circledR}$ inoculation, productivity is greater, enhanced benefits from legumes' ability to fix $\mathrm{N}_{2}$, these research results exhibit that there is a greater grain quality of intercrop maize as a good and attainable potential. Under intercropping system with mungbean, Los Baños Lagkitan is recommended due to its yield advantage over monocrop of the same variety, Los Baños Lagkitan did not show any yield reduction under intercropping system compared with the other varieties, The crude protein of Los Baños Lagkitan is highly notable too (8.98 \pm 0.13$)$. Meanwhile IPB Variety 6 with Mykovam inoculation is recommended for intercropping mungbean for yield advantage, the mungbean planted with IPB var 6 achieved higher yield. This results suggest that Maize-legume intercropping will lead to increase productivity, and reduce crops failure for farmers in Liberia and the Philippines.

\section{REFERENCES}

[1]. Altieri, M. A., Funes-Monzote, F. R., \& Petersen, P. (2012). Agroecologically Efficient Agricultural Systems for Smallholder Farmers: Contributions to Food Sovereignty. Agronomy for Sustainable Development, 32, 1-13. Altoveros, N. C., \& Borromeo, T. H. (2007).

[2]. The State of the Plant Genetic Resources for Food and Agriculture of the Philippines (1997-2006). A Country Report.

[3]. Cely, M. V., De Oliveira, A. G., De Freitas, V. F., de Luca, M. B., Barazetti, A. R., Dos Santos, I. M., \& Andrade, G. (2016). Inoculant of arbuscular mycorrhizal fungi (Rhizophagusclarus) increase yield of soybean and cotton under field conditions. Frontiers in Microbiology, 7, 720.

[4]. Chakraborty, U., \& Pradhan, B. (2012). Drought Stress-induced Oxidative Stress and Antioxidative responses in four Wheat (Triticum aestivum L.) Varieties. Archives of Agronomy and Soil Science, 58(6), 617-630. 
[5]. Chapoto, A., Chabala, L. M., \& Lungu, O. N. (2016). A long History of low Productivity in Zambia: Is it time to do away with blanket recommendations. Working Paper 110, Indaba Agricultural Research Institute (IAPRI), Lusaka.

[6]. Deininger, K., \& Byerlee, D. (2011). Rising Global Interest in Farmland: Can It Yield Sustainable and Equitable Benefits? The World Bank.

[7]. Duncan, E. G., O'Sullivan, C. A., Roper, M. M., Biggs, J. S., \& Peoples, M. B. (2018). Influence of co-application of Nitrogen with Phosphorus, Potassium and Sulphur on the apparent efficiency of Nitrogen Fertilizer use, grain yield and protein content of Wheat. Field Crops Research, 226, 56-65.

[8]. Fang, H., Li, W., Wei, S., \& Jiang, C. (2014). Seasonal Variation of Leaf Area Index (LAI) over Paddy Rice Fields in NE China: Intercomparison of Destructive Sampling, LAI-2200, Digital Hemispherical Photography (DHP), and AccuPAR Methods. Agricultural and Forest Meteorology, 198, 126-141.

[9]. Institute of Plant Breeding (IPB), College of Agriculture and Food Science (CAFS), University of the Philippines Laguna College, 1976, 1989. 200, 2019

[10]. Khalil, Y. (2016). Organization and Management for Efficient Irrigation Water-Use LaCanne, 2017).

[11]. LaCanne, C. (2017). Interactive Effects of Cover Crops, Invertebrate Communities and Soil Health in Maize Production Systems, South Dakota State University. (Doctoral dissertation)

[12]. Mousavi, S. R., \& Eskandari, H. (2011). A General Overview on Intercropping and Its Advantages in Sustainable Agriculture. Journal of Applied Environmental and Biological Sciences, 1, 482486.

[13]. Pozdisek, J., Henriksen, B., Ponizil, A., \& Løes, A. K. (2011) Utilizing Legume-Cereal Intercropping for Increasing Selfsufficiency on Organic Farms in Feed for Monogastric Animals Agronomy. Research, 9, 343-356.
[14]. Rao, M. A., Scelza, R., \& Gianfreda, L. (2014). Soil Enzymes. Enzymes in Agricultural Science. Omics Group eBooks, USA. pp, 10-24.

[15]. Tokatlidis, I. S., \& Koutroubas, S. D. (2004). A review of maize hybrids' dependence on high plant populations and its implications for crop yield stability. Field Crops Research, 88(2-3), 103-114.

[16]. Van Noordwijk, M., Lawson, G., Hairiah, K., \& Wilson, J. (2015). Root Distribution of Trees and Crops: Competition and/or Complementarity. Tree-CropInteractions: Agroforestry in a Changing Climate. CABI, Wallingford, UK, 221-257.

[17]. Vance, C. P. (2001). Symbiotic Nitrogen Fixation and Phosphorus Acquisition. Plant Nutrition in a World of declining Renewable Resources. Plant Physiology, 127(2), 390-397.

[18]. Dingkuhn, M., Singh, B. B., Clerget, B., Chantereau, J., \& Sultan, B. (2006). Past, present and future criteria to breed crops for water-limited environments in West Africa. Agricultural Water Management, 80(1-3), 241-261.

[19]. Mousavi, S. R., \& Eskandari, H. (2011). A general overview on intercropping and its advantages in sustainable agriculture. Journal of Applied Environmental and Biological Sciences, 1(11), 482-486.

[20]. Rola, A. C. (2000). Economic perspective for agricultural biotechnology research planning (No. 2000-10). PIDS Discussion Paper Series.

[21]. Matusso, J. M. M., Mugwe, J. N., \& Mucheru-Muna, M. (2014). Potential role of cereal-legume intercropping systems in integrated soil fertility management in smallholder farming systems of SubSaharan Africa. Research Journal of Agriculture and Environmental Management, 3(3), 162-174.

[22]. Lithourgidis, A. S., Dordas, C. A., Damalas, C. A., \& Vlachostergios, D. (2011). Annual intercrops: an alternative pathway for sustainable agriculture. Australian journal of crop science, 5(4), 396-410. 